\title{
“Znaš, bilo je to...". Povijest, vrijeme i krajolik u predajama iz Slavonije
}

\author{
LJILJANA MARKS \\ Institut za etnologiju i folkloristiku, Zagreb
}

\begin{abstract}
Rad razmatra povijesnu predaju kao dinamičan, živ i produktivan žanr usmene književnosti, usmene povijesti i kulture uopće. Predložak su tekstovi iz četiriju slavonskih zbirki (iz Osijeka, okolice Đakova te Šaptinovaca) i vremenski pokrivaju 20. stoljeće. To je kraj koji nije dao velike junake hrvatskoj povjesnici, što ne znači da u predajama nije bila prisutna svijest o povijesnom vremenu i otiscima priča u njemu jer su predaje uvijek dijalog s prošlošću iz vremenske (i obrazovne) perspektive kazivača, koji, govoreći o prošlosti, ponajprije komentira sadašnjost. Urasle su u zavičajni prostor kao spremišta povijesne memorije i iskustava zajednice. Vremenski, povijesni, ipak ponajprije lokalnopovijesni, topografski slojevi iščitavaju se iz njih onoliko koliko to zapis nudi. U radu se tumače naoko skriveni markeri lokalnoga krajolika, identiteta, povijesnih okolnosti, doba zapisa, osobnih kazivačkih reminiscencija. Interpretirani su događaji narativno konstruirani kao predaje na granici memorata i mitskih predaja i prepričavanjem se svaki put iznova aktualiziraju.
\end{abstract}

Ključne riječi: predaja, topografija, kultura sjećanja, Slavonija, Hrvatska

Polazim od možda najpoznatije i do danas najcitiranije odrednice dvaju reprezentativnih proznih žanrova - bajke i predaje. Premda napisana u uvodu knjizi Njemačke predaje (1816 - 1818), kao differentia specifica obaju žanrova u temeljnim premisama vrijedi i danas:

Bajka je poetičnija, predaja je povjesnija; svaka je gotovo sama u sebi čvrsta, u urođenom cvatu i dovršenosti; predaja s manjom raskoši boja ima i ono posebno što prianja uza poznato i znano, uz jedno mjesto ili uz poviješću potvrđeno ime. Iz te povezanosti slijedi da ona, u usporedbi s bajkom, ne može svugdje biti kod kuće jer pretpostavlja uvjet bez kojega ne bi bila tek nepotpuna, već je ne bi ni bilo. (Grimm 1993: 15) ${ }^{1}$

Poetičnost bajke dosad nije dovedena u pitanje, ali su o otiscima povijesti u predajama ispisane nebrojene stranice (Dégh 2001; Tangherlini 1990). Nije to zbog zastarjelosti ili nedostatnosti Grimmova određenja, nego zbog

\footnotetext{
${ }^{1}$ Prijevod s njemačkog je autoričin.
} 
neukrotivosti i neomeđenosti tog iznimno živog, produktivnog i dinamičnog žanra usmene književnosti, usmene povijesti i kulture uopće. Predaje su uvijek dijalog s prošlošću iz vremenske (i obrazovne) perspektive kazivača, koji govoreći o prošlosti ponajprije komentira sadašnjost. Urasle su u zavičajni prostor kao spremišta povijesne memorije i iskustava zajednice. Vremenski, povijesni, ipak ponajprije lokalnopovijesni, topografski slojevi iščitavaju se oduvijek iz usmenoknjiževnih tekstova onoliko koliko to zapis nudi. Nastojala sam za ovu prigodu pronaći i naoko skrivene markere lokalnoga krajolika, identiteta, povijesnih okolnosti, doba zapisa, osobnih kazivačkih reminiscencija.

Tekstovi na kojima ću to pokazati su iz četiriju slavonskih rukopisnih zbirki: iz Smičiklasove zbirke prikupljene šezdesetih godina 19. stoljeća u Osijeku i okolici, iz zbirke Milene Papratović iz okolice Đakova iz tridesetih godina 20. stoljeća, iz rukopisne zbirke Maje Bošković-Stulli iz Gorjana i Potnjana godine 1957. te iz moje zbirke iz Šaptinovaca 1974. i 1975. godine. Sve su zbirke nastale prema izravnim kazivanjima priča: Smičiklasovu su, prema njegovu kasnijem svjedočenju, zapisivali gimnazijski učenici, ${ }^{2}$ M. Papratović je sama ručno bilježila priče za vrijeme kazivanja u kućama svojih kazivača, M. Bošković-Stulli je radila to isto u Gorjanima i Potnjanima, a zbirka iz Šaptinovaca je snimana magnetofonski. ${ }^{3}$

Smičiklasove su pripovijetke zabilježene godine 1863./64. ponajviše u Donjem gradu u Osijeku, gdje je tada, s dvadeset godina i nakon završene gimnazije, a prije studija povijesti i zemljopisa, bio gimnazijskim profesorom hrvatskoga jezika i povijesti. Riječima samog Smičiklasa između godina 1874. i 1879., kad je rukopis poklonio Akademiji (SZ 2, 148 str.): "Ove su pripovijesti sabrane prije dvadeset i pet godina oko Osijeka - pisali su ih djaci i ostalo je onako kako su oni pisali. Ima u njima i dobrih materijala. Poklanjam Akademiji." Zbirka je važna za sva povijesna istraživanja pripovijedanja u Hrvata jer promovira priče u doba kad su još uvijek bile zanemarenim (barem sekundarnim) žanrom u odnosu na pjesništvo. ${ }^{4}$ To je ujedno najstarija slavonska ciljano prikupljena zbirka s objavljene 63 priče u četirima brojevi-

\footnotetext{
${ }^{2}$ Matija Kračmanov Valjavec, priređivač prve dijalektalne zbirke hrvatskih priča (Narodne pripovjedke skupio u i oko Varaždina. Varaždin, 1858., 1890².), bio je također gimnazijski profesor i tekstove su prikupljali učenici i njihovi roditelji.

${ }^{3} \mathrm{Ne}$ uključujem u ova razmatranja iznimno bogate i vrijedne zbirke što su prikupljene u Posavini: Luke Ilića Oriovčanina (Slavonski narodni običaji, gdje ima i pripovijedaka), Luke Lukića (neobjavljene zbirke iz Varoša i Klakara), Jurja Lesara (iz Podgajaca). One bi jednako, neke čak i bolje, mogle oprimjeriti vezu između lokalnog, povijesnog, tradicijskog, mitskog, fikcijskog.

${ }^{4}$ Mijat Stojanović je bio dotada najmarljiviji skupljač i objavljivač priča i izdao je nekoliko zbirki narodnih pripovijedaka većinom iz Slavonije. Skupljao ih je tridesetak godina, stilski i jezično ih prepravljao i uređivao uglavnom po uzoru na zbirke V. Karadžića (Stojanović 1867, 1879, 1879a). A kako je svoj posao prostodušno shvaćao, vidimo iz pisma Ljudevitu Gaju godine 1846.: “Zabavljam se sastavljanjem naših prostih pripovestih; sabiram ih; izdelavam; izgladjivam; krojim; šijem, param, čupam, sadim, uredjujem ili ostavljam onako, kako jest u ustih puka (Horvath, Josip/Jakša Ravlić 1956: 435).
} 
ma Zbornika za narodni život i običaje (i nikad poslije otisnuta kao cjelina); nema podataka o pripovjedačima, jezično je uređena prema onodobnom standardu: ijekavizirana je, ali su ostavljeni brojni lokalizmi, germanizmi, hungarizmi, srbizmi, turcizmi i leksemi koji su danas arhaizmi, a tada su sigurno bili dijelom svakidašnjega govora.

U Smičiklasovoj zbirci nema osobnih pripovjedačkih interpolacija, nisu ni očekivane. Zato je navodim na početku kronološkog niza slavonskih zbirki: impersonalna je, indiferentna u odnosu na kazivače jer su bili nebitni. Bio je bitan tekst koji je ipak samo do neke mjere dotjeran i usklađen - pretpostavljam - prema Vukovim ili Stojanovićevim (što se svodi gotovo na isto) modelima obrade teksta, ili pak prema Akademijinim priređivačkim pravilima. ${ }^{5}$ Začudno je što nema ni jednog detalja koji bi bio neposredno vezan uz Osijek kao što je gotovo nevjerojatno da nije spomenut ni jedan lokalitet, ime, ali takvi možebitni tekstovi (predaja) su očito ostali izvan Smičiklasova zanimanja i izbora za tisak.

Milena Papratović je objavila 1940. godine 41 pripovijetku u Zborniku za narodni život i običaje (br. 32/2), koje je skupila 1935. i 1936. u Đakovačkim Selcima, Punitovcima i Pridvorju. Stanovnici su bili Hrvati, Nijemci i Mađari te ponešto Slovaka u Punitovcima, u nejednakim brojčanim odnosima u pojedinim selima. Navela je samo devet kazivača, od kojih sedmero vrlo mladih (od 10 do 16 godina), s uglavnom završenom osnovnom školom (četiri ili šest razreda). Rad oko skupljanja pripovijedaka olakšala joj je Katica Popanka, učiteljica u Đakovačkim Selcima, jer je unaprijed priredila tlo tražeći u selu među odraslima i među djecom one koji znaju pripovijedati "pripovitke". "Bez njezine pomoći ne bih tako uspješno i brzo završila svoj rad, jer ne bih stekla potpuno povjerenje kazivača, koje je pri tom bezuvjetno potrebno" (Papratović 1940: 87). Tom smo se metodom služili i poslije, pokušavajući uvijek u selu krenuti od učiteljice ili svećenika.

Pripovijetke su zabilježene onako kako su ih kazivači govorili. Budući da je lokalni govor istraživačici bio dobro poznat, nastojala je tekstove zabilježiti što točnije, do čega joj je u istraživanjima "bilo naročito stalo" (Papratović 1940: 87). Poticala je kazivače da kazuju samo one pripovijetke koje su čuli od svojih starijih, a koje nisu bilo gdje čitali. U tekstovima ostavlja ikavicu te su ti tekstovi mnogo bliži običnomu govoru od, recimo, Smičiklasovih zapisa, ali ni u nje nema pripovjedačkih umetaka (poštapalica, komentara teksta, pripovjedačevih intervencija u tekst, opisa pokreta za vrijeme pripovijedanja). To je, naravno i zbog medija: zapisivanje rukom je teže od magnetofona. A cilj joj i nije bio zapisati sve što pripovjedač kazuje, već što bolje pratiti radnju (tip priče) i zapisati je jezično što vjernije. U komparativne primjere, inačice, uvrštava samo objavljene cjelovite zbirke priča iz cijele Hrvatske

\footnotetext{
${ }^{5}$ Smičiklas daje nazive svojim pričama (za razliku od Lesara i Papratovićke poslije).
} 
(dijelom i iz Bosne te iz Vukove zbirke priča), ali ne uključuje pripovjednu građu objavljenu u Zbornicima za narodni život i običaje. To je razumljivo ako uzmemo u obzir da je skupljala gradivo za svoju doktorsku disertaciju pod mentorstvom prof. Gavazzija pa je morala uvažavati i njegove primjedbe oko skupljanja i interpretacije tekstova. Jezične je zahtjeve pred nju postavljao prof. D. Boranić, jezikoslovac, urednik Zbornika. Vidljivo je to iz intenzivne prepiske M. Papratović i prof. Gavazzija (Hrvatski državni arhiv, M. Gavazzi, korespondencija, kutija 87 Pap - Pli). ${ }^{6}$ U središtu njezine doktorske disertacije nije bilo prikupljanje i folkloristička obrada tekstova, nego komparativni pristup prema priručniku Anmerkungen zu den Kinder- und Hausmärchen der Brüder Grimm Johannesa Boltea i Jiřija Polívke iz 1918. te registru tipova pripovijedaka Anttija Aarnea iz 1910., Verzeichnis der Märchentypen, koji je Stith Thompson proširio i dopunio 1927. te na engleskom objavio $1928 .^{7}$ To je prva zbirka hrvatskih priča koja je bila klasificirana prema tome modelu, koji dopunjen traje i danas.

Njezin komparativni pregled upućuje da se najviše srodnih varijanata i paralela nalazi u zbirkama koje su prostorno udaljene od te zbirke iz okolice Đakova. Najviše srodnosti pokazuju ponajprije zbirke R. Strohala, zatim M. K. Valjavca, F. S. Kraussa, pa pojedine pripovijetke zabilježene u časopisima i zbirkama iz Bosne (osobito u Bosanskoj vili). Je li to stoga što su to (osim Kraussove) bile dijalektalne zbirke koje su nastajale prema izravnome pripovijedanju, ostaje nam istražiti. U zbirci M. Stojanovića, makar je prostorno najbliža ovoj, nije bilo očekivanih paralela i varijanata. Sama Papratović nastoji to objasniti time "što se M. Stojanović u sakupljanju pripovijedaka nije ograničio ni vremenski ni prostorno, tj. nije se ograničio na uži geografski prostor, te njegov rad nije bio na takvom prostoru sistematski i intenzivan, kako to na pr. vidimo u Strohala i Valjavca" (Papratović 1940: 178). Iz Smičiklasove je zbirke navedeno sedam varijantnih primjera. Pripovijetke iz Bosne i Hercegovine pokazuju tijesnu srodnost sa slavonskima, odnosno s tim pripovijetkama iz okolice Đakova. To je očekivano prije svega zbog intenzivnih migracija iz Bosne u Slavoniju i vjerojatno su pripovijetke doseljenici donijeli sa sobom. Usporedna detaljna raščlamba motiva i tipova priča sa starijim i novijim zbirkama sigurno bi mnogo otkrila. Vraćamo se onom suptilnom, gotovo skrivenom "slavonskom" sloju koji ta zbirka otkriva više od Smičiklasove. Prvo, tu prevladava ikavica koja odmah drukčije situira

${ }^{6}$ U Hrvatskom državnom arhivu (kutija 87) se čuva korespondencija M. Gavazzija, u kojoj je i prepiska s Milenom Papratović oko izrade njezine doktorske disertacije. Sačuvano je 30 pisama, 23 dopisnice i jedan novinski isječak uložen u pripadajuće pismo. Na poleđini Papratovićkinih dopisnica nalazi se i njegov odgovor, pa tako možemo pratiti cjelovito dopisivanje. Prvo je Papratovićkino pismo datirano 13. 11. 1937. i dopisivanje je trajalo do 14. 4. 1940.

${ }^{7}$ Aarne-Thompson: "The types of the folk-tale", F. F. Communications, br. 74 (1928); 19612; riječ je o znamenitom AT-katalogu, koji je godine 2004. znatno dopunio i pisanim izvorima Hans-Jörg Uther. Objavljen je kao i prethodna izdanja kataloga u časopisu FF Communications, br. 284 i 285. 
tekstove. Dijalozi među likovima, pa i kad su protagonisti kraljevi i kraljice, mnogo više odgovaraju svakodnevnu govoru no književnom biranom jeziku. Susrećemo lugare u šumama, prijetnje biskupu, gledamo vinograde, livade... Nema predaja pa ni stvarnih povijesnih osoba. Ali tu je Aršanj, vrh u susjednoj Mađarskoj i mitsko slavonsko okupljalište vještica. Kristijanizirane su pa u potpuno bajkovitom prostoru nalazimo svećenike, božji blagoslov, pijev anđela; obiteljski odnosi između majke i lijene kćeri, zeta, snahe i svekrve prerastaju neutralni tip priče o lijenoj ženi.

Zbirka Maje Bošković-Stulli se na neki način nastavlja na zbirku Milene Papratović pa i u repertoaru možemo pratiti trajne i promjenjive tekstove. Obje su zbirke postale kanonskima u istraživanjima Slavonije.

Maja Bošković-Stulli je na teren u Gorjane i Potnjane krenula 1957., kako sama navodi u rukopisnoj zbirci, potaknuta istraživanjem Milene Papratović. Konstatira u uvodu zbirci kako je njezina građa drukčija od zbirke M Papratović, što samo govori o raznolikosti građe u istome kraju. Međutim upravo iz zbirke M. Papratović potječe bajka o zmiji mladoženji (br. 9), koju je Maja Bošković-Stulli uvrstila gotovo uvijek u paru sa svojim zapisom priče Babina Bilka u sve antologijske izbore hrvatskih priča. ${ }^{8}$

To je na neki način i priča o skupljačicama, dakle o ženama na slavonskome terenu koje istražuju drukčije no prije: nisu prepustile djeci da bilježe priče ili čekale da im pripovjedači dođu u seosku školu, nego su ulazile u njihove kuće, išle za njima na pašu i u polje, opisivale kazivače, pripovjedačke, ujedno i obiteljske situacije, dakle neposredan živ kontekst priča.

Moja je zbirka Narodne pripovijetke, predaje i pjesme iz Šaptinovaca (Slavonija), I. IEF Rkp 930. nastala 1974. i 1975. za terenskih istraživanja u Šaptinovcima. Snimala sam magnetofonski. Poslije sam u nekoliko navrata odlazila u selo: snimala sam i iste kazivače i iste priče da vidim promjene motiva, život žanrova... Budući da je riječ o magnetofonskim zapisima koji su vjerno prenijeli živu riječ, lakše se iščitavaju i jezične i stilske nijanse. Tematski korespondiraju sa starijim spomenutim zbirkama, ali, kako sam snimala sve što se govorilo, ima više predaja, osobnih doživljaja, prepričanih priča iz školske lektire. Priče nisu objavljene, osim rijetkih tekstova u izborima priča. Na jezičnoj je razini tada još uvijek bio u velikoj mjeri sačuvan staroštokavski idiom, ponajviše u tekstovima koji su evidentno usmeno prenošeni i pripadaju tradicijskom sloju pripovijedanja.

Već i površno čitanje tekstova od Smičiklasa do danas pokazuje velike promjene u broju tekstova podarenih pojedinomu žanru: u Smičiklasa su

${ }^{8}$ Te su se obje bajke, Babina Bilka i Zmija mladoženja našle zajedno u izborima priča koje je priredila Maja Bošković-Stulli: u Pet stoljeća hrvatske književnosti, knj. 26 (1963: br. 28 i br. 29.), u Stoljećima hrvatske književnosti (1997: br. 6 i br. 15), u njemačkoj ediciji Die Märchen der Weltliteratur (1975: br. 1 i br. 12). Babina Bilka je dramatizirana u varaždinskom kazalištu, više puta izvedena na radiju, o njoj je snimljena i dokumentarna televizijska emisija. Objavljena je i u zbirci Šingala-mingala (1983: br. 9). 
dominantne bajke, i to veoma dugi tekstovi, slijedi poneka šaljiva priča; nema ni jednoga podatka o pripovjedačima, o eventualnom literariziranju, ijekaviziranju, možda prema uzoru na M. Stojanovića. ${ }^{9}$

Papratovićka donosi uz bajke i šaljive priče i predaje (ali ih ne izdvaja i uključuje samo one koje mogu biti i katalogizirane prema Aarneovu katalogu). Ne znamo što je ostalo u rukopisima, možda i nije zapisivala tekstove koji nisu pripadali "klasičnom" repertoaru. M. Bošković-Stulli ipak ima rukopisnu zbirku u kojoj je skupljeno sve što je toga trena bilo na terenu, dakle, nema autorskoga "čišćenja" i izbora tekstova, ali već dominiraju predaje; važnost pojedinačnih zapisa ipak je poslije odredila M. Bošković-Stulli objavljujući izabrane tekstove u svojim antologijskim zbirkama. U mojoj zbirci pretežu predaje, premda su brojne i bajke, katkad vrlo kratke, krnje, gotovo torza u kojima se prepoznaje motiv; velikim su dijelom iz Grimmovih zbirki ili školske lektire (Vuk), ali i iz tradicijskoga repertoara. Slijede šaljive priče te podosta tzv. doživljaja iz života. Pokazuje to promjenu percepcije o važnosti pojedinih pripovjedačkih žanrova i u skupljača i u pripovjedača unutar više od sto godina. Valja uzeti u obzir i odnos prema žanrovima koji se mijenjao s vremenom: bajka je u 19. stoljeću, i dugo poslije, bila reprezentativni žanr i uvijek se nalazila na uglednim mjestima (počecima) zbirki. Slijedile su šaljive priče, novelističke (svagdanjske) i to je uglavnom bilo sve, eventualno pokoja legendarna pripovijest. Svijest o mnogo raznolikijem usmenom proznom repertoaru i jednostavno drukčije poredanoj hijerarhiji žanrova u kazivača, dugujemo drugoj polovici 20. stoljeća i zbirkama koje nastaju nakon neposrednih terenskih istraživanja. Stoga je veoma teško pouzdano govoriti koji su tekstovi doista prevladavali u neposrednom pričanju u pojedinoj zajednici. Znamo da se sve nije zapisivalo. Vidimo to veoma dobro iz Papratovićkinih priča, u kojima su neki tekstovi (koje bismo danas uvrstili u predaje o mrtvima) podudarni Lovretićevim zapisima vjerovanja o mrtvima koji su od njezinih istraživanja stariji gotovo pola stoljeća. ${ }^{10}$

Relativna kratkoća, žanrovska zamućenost i stilska rogobatnost suvremenih zapisa (Bošković-Stulli i Marks) nije dokaz o slutećem "kraju priče". Ti zapisi nisu ni mikropriče ni postpriče. Oni su otisak svojeg vremena. Brojnost, različitost i prepletenost glasova i zapleta u njima te narušena

\footnotetext{
${ }^{9}$ Lesar je bliži Papratovički, ali je podjednako uronjen i u “starinsku” skupljačku metodologiju: donosi imena i dob kazivača, zanimanja, zapisuje prema pričanju, ali ih štokavizira.

${ }^{10}$ Lovretić donosi 18 tekstova vjerovanja o mrtvima, od kojih većinu motiva pronalazimo poslije, $\mathrm{u}$ zbirkama priča, a i danas kao još uvijek živ dio repertoara (Lovretić 1990: 537- 551); vidi Bošković-Stulli, IEF Rkp. 259, br. 23; Marks, IEF Rkp. 930: br. 15, 18, 29; Papratović napominje u fusnoti uz priču br. 15 (str. 133) da je zovu "Od mrtvih". Navode se varijante u sljedećim zbirkama: Valjavec, Strohal (četiri primjera), Plohl-Herdvigov (tri primjera), Dokušec. Ne spominje se Lovretić premda je donesena priča najsličnija njegovu tekstu br. 7 (Lovretić 1990: 542-543). Lovretićevi su zapisi mnogo bogatiji lokalnim detaljima: imenima djevojaka, kuća iz kojih potječu, sela, dakle danas bismo kazali da su bliže izvornu kazivanju. Lovretićeva monografija je izlazila u ZNŽO u nastavcima od 1897. do 1918. i bila je sigurno znana M. Papratović.
} 
tradicijska linearnost pripovijedanja ugrožava često proklamiranu i poželjnu ideju kontinuiranog iskustva svih prethodnih naraštaja. ${ }^{11}$ Unatoč svemu nisam sklona pretkazivanjima o nestanku neposrednog pričanja priča. Dok god bude nekoga tko će kazati - "Ispričaj mi priču", "Reci, kako je ono bilo", "Sjećaš li se kad smo", "Znaš, bila je istina da..." - i nekoga tko će spremno odgovoriti, priče će se pričati.

Kad sam odlučila obraditi spomenute slavonske zbirke, bila sam sigurna da ću u tekstovima koji evociraju povijesno vrijeme i događaje jednostavno pronaći "uobičajene" figure i postupke. Iznenadila sam se kad ih nije bilo, barem ne u očekivanu rasponu. Nisam odustajala od teme i ponovno sam iščitavala i tekstove i sekundarnu literaturu i shvatila da je tih detalja mnogo, ali su u tekstovima nenametljivi. Nije ih bilo najviše tamo gdje sam ih očekivala (u povijesnim predajama, šaljivim pričama, anegdotama), već u mitskim predajama, čak i u bajkama.

Navest ću ih redom od očiglednih do rijetko evidentiranih u usmenim proznim korpusima.

\section{LEKSIK}

U jezični sloj priča uvijek je upisan kraj, lokalizmi, idiolekt pripovjedača - i to su opća mjesta u filološkim interpretacijama ponajprije prozne usmenoknjiževne građe. I leksemi iz Smičiklasove zbirke suptilno otkrivaju upravo osječki gradski, a potom i slavonski supstrat: imena junaka - Šandor, Jula, Švabe; zanimanja - biroš, pendant, parok; pustahije, soldati, husari, hajduci...; nazive novca - dukati, krajcari, forinte; oružja - handžari... jela - šunka, vino, rakija, od slanine kuća...; predmeta u kući - furuna; uzvika Holt!.

Ostavljene i sačuvane njemačke, zapravo esekerske njemačke riječi (frajli$c e$, holt!), poneke mađarske, zrcale sliku koja je poslije toliko puta obnavljana u hrvatskoj književnosti - od Vilme Vukelić do suvremenih romanopisaca (primjerice, Unterstadt Ivane Šojat Kuči, Hedlova Donjodravska obala) - i koja danas pokriva afektivni dio svake lokalno usidrene naracije. Sličan fundus leksema koji svjedoči o lokalnome i povijesnome nalazimo i u ostalim zbirkama: koleba, zužunak obala, grofovi, grofice, soldati, razbojnici, lopovi, fijaker, henc konji, bačika, nenika, pašnik, paševnik...

${ }^{11}$ Staru komunikaciju i priče već dugo podrivaju mediji, a posljednjih desetljeća intenzivno elektronički mediji. Oni im istodobno podaruju nov život jer mediji preuzimaju mjesto starih mnemotehničkih (i tiskanih) načina izražavanja. Tu se iz temelja mijenjaju i ideje o ukorijenjenom prostoru u tekstovima jer u beskrajnom mrežnom megapolisu vladaju sve veće brzine i neposrednost (Kearney 2009: 128). To se najbolje vidi u suvremenim urbanim predajama koje motivski i tematski najčešće nisu usidrene $u$ tradicijski kontinuitet, ali ih lokalna mjesna obilježja i imena protagonista povezuju sa starim gradivom. 
Priče su - pogotovo unutar više od sto godina koliki je ovdje razmak između najstarije i najmlađe zbirke - promijenile svoj jezik: ono što je u Smičiklasovim pričama svakidašnji jezik, u zbirci iz Šaptinovaca pripada arhaizmima, ali nema diskontinuiteta u tradiciji između tih zbirki da bismo o Smičiklasovoj mogli govoriti kao o "staroj" koja rekonstruira prošlost. Jezične su promjene spore i govornici ih u normalnim (vremenskim) odnosima nisu svjesni. Postajemo ih svjesni usporedbama starijih i novijih zapisa. Priče ne pripadaju tekstovima koji imaju status svetih tekstova (poput molitvica ili formula) pa su otvorene i jezičnim promjenama i osobnim kazivačevim jezičnim intervencijama. Ono što su u starijim zbirkama uobičajeni leksemi, u mlađima mogu biti stilemi (a i ne moraju, mogu biti jednostavno lokalizmi, arhaizmi i sl.).

\section{POVIJEST I VRIJEME}

Priče iz Slavonije vrlo rijetko imenuju svoje velikaše ili "velike muževe" (riječima Mirjane Gross) kao protagoniste povijesnih ili mitskih predaja, što ne znači da nije bila prisutna svijest o povijesnom vremenu o kojemu bi priča mogla govoriti. U mlađim se zbirkama redovito raskriva kazivačevo poimanje povijesti koje zahvaća prijelomne međašne točke koje su bile prekretnicom ne samo u dalekome svijetu nego i u toj malenoj sredini i od kojih se vrijeme broji na ono prije i poslije (Prvi i Drugi svjetski rat, vjerojatno će to postati i Domovinski), važnost lokalnih velikaša (grofova) koji zamjenjuju uobičajeni feudalni bajkovni svijet, avanturu lokalnih junaka (baruna Trenka u pričama koje su vezane uz Habsburgovce, a mjestom uz Osijek, Požegu, Našice), hajduka, odmetnika (poimence Čaruge), ugledne osobe iz hrvatske kulture (Strossmayer) koje su glavni likovi u događajima iz lokalne zajednice. Prepričani su događaji narativno konstruirani kao predaje na granici memorata $i$ mitskih predaja koje pritom zrcale povijesnu svijest svoje sredine, markiraju stalne i čvrste povijesne kote i mitska mjesta koja prepričavanjem svaki put iznova aktualiziraju.

Biskup Strossmayer je nezaobilazna povijesna osoba u okolici Đakova, ali je i lik u predajama, "Štrocmajer". Bilo bi čudno da ga nema i on potkrepljuje tezu o tome da lokalna povijesna memorija jako dugo pamti svoje junake i važne osobe, oni su metafore društva i trajanjem premašuju svoje stvarno životno doba. O Strossmayeru kao o glavnome junaku u zbirci M. BoškovićStulli nalazimo pet tekstova. Oni su anegdotalni, ali pomnije čitanje pokazuje da je riječ o tipskim povijesnim ili mitskim predajama situiranima u domaće okružje. ${ }^{12}$ Govorili su ih ljudi koji se nisu ni rodili (ili su bili mala djeca) kad

${ }^{12}$ Biskupov otac je trgovao konjima, ali je katkad od Cigana uzimao ukradene konje, koje je poslije vlasnik našao u Strossmayerovoj ergeli. Strossmayer u priči ispravlja očev "grijeh" i vraća konje vlasniku, 
je Strossmayer umro, dakle nisu imali izravan dodir ni s njim ni s tim vremenom, premda katkad o njemu govore kao neposredni svjedoci, u prvome licu ili se pozivaju na stvarnog aktera tematiziranog događaja. Kazivač rođen 1896. ubacuje u predaju o noćnome lovcu Peji rečenicu: "To je istinito, to je sve bilo", a M. Bošković-Stulli navodi u bilješci komentar publike upravo na tu interpolaciju: "Neki prisutni prepiru se s njime, tvrdeći da to ne može biti" (IEF Rkp. 259: 19). Ista je interpolacija i u predaji o tuči koju može izazvati i spriječiti pop. Stvarni svjedok, Josip Janošek, Pido, akter neugodna doživljaja i "autor" priče višestrukim detaljima potvrđuje istinitost:

[...] i kad su došli do Selaca i tudek ji stigne ta oluja i biskupa izvrni iz fijakera - to je istinito bilo - kaže Pido kotrljo ji je vjetar, kotrljo po putu i pokidali fijaker, nakisli, istučeni bili. (IEF Rkp. 259: 21)

Istina iskazana riječima kazivača narativu ne jamči istinitost, to znaju svi koji su se susretali s tim tipovima tekstova, to je najčešća stilska figura koja prizivanjem istine i opisom detalja svjedoči o aktivnom angažmanu kazivača, a predajama podaruje afektivnost. Motivi o kojima te predaje govore pokazuju da je riječ o usmeno prenošenim tipskim predajama koje prelaze granice lokalnog događaja: čarobni strijelac, divlji lovci, pop/mladomisnik/

dakle postupa kao pravedni vladar iz svake predaje. Međutim, saznajemo da je otac svjesno uzimao ukradene konje da bi mogao školovati sina. To je tipski motiv koji se veže i uz don F. Bulića: za njega se pričalo da je za iskopavanja u Solinu našao zlatnu kokoš s pilićima i da se tim novcem školovao u Beču (IEF Rkp. 259: 14-15).

Lovac Pejo (o kojemu nalazimo dva teksta) je na Veliki petak pucao kroz maramicu na sunce, što je kršćanima zabranjeno. Njome je brisao pušku i ona je nakon toga sama svaki put u lovu opalila. Lovio je u "Štrocmajerovoj" šumi zečeve sa zavračanim psom pa je priveden pred biskupa, koji mu oprašta, ali i predviđa brzu smrt (IEF Rkp. 259: 16-20). Nakon smrti postaje dijelom vojske "divljih lovaca", noćnih jagara, dakle mrtvih, prokletih, nesmirenih grješnika koji noću nevidljivi zauvijek hode ili lete po šumama i koje lajanjem prate psi. To je jedan od najstarijih pripovjedačkih europskih motiva, iskorištavan i u hrvatskoj književnosti (Milutin Mayer), a zbiljnost ovdje ostvaruje vežući se uz Strossmayera.

Strossmayer je sa župnikom iz Gorjana bio u gostima kod župnika u Trnavi. Župnik iz Gorjana je iz oblaka zaključio da će biti tuče, i nagovarao biskupa da pričeka. On nije povjerovao i na putu mu se izvrnuo fijaker. Gorjanski pop je isto tako otputovao, dostigla ga je tuča, ali je sišao s kola, uzeo knjigu, prijetio prstom i izgovarao: - Kolega - kaže - mir!. Dok je čitao iz knjige, oblak se raskinuo i nije više padalo. Kočijaš je u oblaku vidio čovjeka kako jaše na "aždaji". Pripovjedač komentira: "To je bio drugi pop, bogzna otkale, ćeo da se osveti ovome." Sljedećeg je dana župnik iz Gorjana priznao biskupu da ima nadnaravne sposobnosti. Priča je samo do neke mjere anegdotalna - spominje stvarna mjesta, župnike ali motivski potpuno odgovara predajama o grabancijašima, mladomisnicima, učenicima tzv. Crne škole koji mogu i napraviti i spriječiti tuču i lete na zmajevima. Motiv se katkad veže i uz župnike, popove, pogotovo u Slavoniji, te je obični događaj u interpretaciji biskupova sluge postao predajom (IEF Rkp. 259: 20-21; Marks 2009).

Zgoda o Strossmayerovoj obrani slavenstva je prava tipska povijesna predaja: Strossmayer ide u sabor u Peštu braniti slavenstvo, s njim je njegov sluga Josip, koji je čuo nekoga Mađara da je opsovao biskupu boga, proglasio ga brbljavcem i zaprijetio da će sljedeći put biskupu sabljom odsjeći glavu. Biskup nakon nekog vremena opet ide u Peštu braniti slavenstvo, ali umjesto Josipa ide drugi sluga. Kad je isti Mađar izvukao sablju, sluga je skočio i sablja mu je odsjekla ruku, ali je biskup ostao netaknut (IEF Rkp. 259: 23). 
grabancijaš koji može napraviti tuču i letjeti na zmaju, prijevarom stečeni novac za školovanje kasnije uglednih osoba, ali i obrana slavenstva u Pešti te ključna uloga biskupova sluge u ostalim tekstovima o Strossmayeru. ${ }^{13}$ Time biskup Strossmayer kao stvarna i pomalo mitska figura ulazi u personaž likova hrvatske usmene tradicije kao i ban Jelačić, Josip II., Marija Terezija itd.

Snaga se povijesne predaje skriva u njezinoj sposobnosti da obrne odnose snaga i da u utopijskom prostoru osigura pobjedu malog čovjeka, lokalnog junaka, anonimnog u velikoj povijesti. To je uloga Strossmayerova sluge u Budimpešti, Pidina uloga kao svjedoka u prevrtanju kola u tuči, ali i u priči o lovcu Peji. "Taj prostor štiti oružje slabih od stvarnosti postojećeg poretka. Također ih zaklanja od društvenih kategorija koje 'stvaraju povijest' jer njome vladaju. I tamo gdje historiografija pripovijeda u prošlom vremenu o strategijama uspostavljene moći, te 'čudesne' pripovijesti nude svojoj publici (poklon dobrom slušatelju) izbor raspoloživih taktika u budućnosti” (Certeau 2002: 75). Povijest je u pričama bila uvijek shvaćana i kao naracija, kao pripovijest - podsjetimo se samo priča o postanku gradova, rodova i naroda koje su gotovo uvijek na početku svih povijesnih pregleda - izvan priče nema ničega jer je svaki događaj nevažan, nepostojeći ako se nekomu glasno, biranim rečenicama ne ispripovjedi, prepričava potom i dalje prenosi. Priče tkaju većinu naših znanja o povijesti: osobnoj, mjesnoj, lokalnoj, velikoj i uvijek se pritom zatečeni pitamo "a gdje sam tu ja?". Naći svoje mjesto svojom pričom u bilo kojoj od povijesti ključno je za dobar, siguran osjećaj u svojem vremenu, ali i zalog za ona buduća. Stoga se i imenom i prezimenom pojavljuje mnogo potpuno anonimnih, tzv. malih ljudi u povijesnim ili mitskopovijesnim predajama jer dodir s važnim i uglednim osobama svojega doba (primjerice, Strossmayerom), odmetnicima, hajducima (Čarugom), čak i s mitskim bićima, preduvjet je važnosti ispripovijedane priče, a to iskustvo otvara snoviti svijet mogućnosti. Ako je uloga tog neznanog junaka (katkad pripovjedača) bila ključna u opisanome događaju, jamči mu kadšto i bijeg iz anonimnosti i ime u povijesnome vremenu. Priča unosi smisao u povijest $i$ sklad u život tih junaka (pripovjedača) jer im omogućuje da svaki događaj ponovno oblikuju prema vlastitu viđenju. ${ }^{14}$ Bez priče naši su životi fragmentarni, iscjepkani i upravo je naracija "jedan od najvitalnijih oblika našeg identiteta - individualnog i zajedničkog" (Kearney 2009: 14). Cilj tih priča nije da se samo jednom ispriča nešto što se dogodilo (ili se nije dogodilo), nego da se ponovno ispriča ono što je mnogo puta ispričano. Osim toga takva priča u zajednici (ili u obitelji) počinje funkcionirati kao zajednička priča jer

${ }^{13} \mathrm{Ne}$ isključujem anegdote ili crtice iz biskupova života koje su mogle biti objavljivane u različitim publikacijama.

${ }^{14}$ To, naravno, još više vrijedi za osobne priče, autobiografske zapise, priče iz života i slične žanrove. Uz komunikacijsku sastavnicu repetitivnost je jednako tako gradbena sastavnica priča. 
ispričano iskustvo pojedinca daje alibi za tu istu priču i većini koja je sluša, premda u njoj nije sudjelovala. ${ }^{15}$

Uvodni su dijelovi priča neizmjerna riznica osobnih reminiscencija i afektivnih odnosa prema priči u lokalnoj zajednici, ali i vremenskih odrednica. Iščitavamo ih u napomenama istraživača, ali, mnogo bolje, u zapisima pripovijedanja. ${ }^{16}$

Ja ću vam pripovidat što je men' moj otac pričao. Bila velika omarina ko danas, a nije bilo dugo kiše, a oni sjeli u vodenicu pa pripovidaju uveče, u noći, kako nema kiše i kako je bilo u staro doba, kad su se orvali sa vukovima i kurjakima i medama i kako su vukodlaci dolazili, i od sviće one dvi što po polju odaju, od inđilira. Kad najedanput samo što oni pripovidaju, al' eto ti u vodenicu uniđe ljudeskara veliki, jedva u vodenicu stao. (IEF Rkp 259: 3)

Uvodi u priče su katkad istodobno i višeglasni i viševremenski: tu u prvome planu slušamo i pratimo glas aktualnog pripovjedača i uživljavamo se u sparinu, "omarinu", slavonskog ljetnog dana koja ga je podsjetila na očevu priču. U istome uvodu čujemo i glas njegova oca od kojega je čuo priču, glas potonuo u još starije doba, koji pripovijeda o istoj takvoj davnoj noći u vodenici kad nije bilo kiše... U očevu je glasu sačuvana pripovjedačka atmosfera i svi glasovi tada prisutnih koji su se prisjećali "kako je bilo u staro doba". To prisjećanje doista seže u staro, gotovo mitsko i bezvremeno doba, kad su se hrvali s vukovima i medvjedima i kad su izlazili vukodlaci, svećice i inđiliri... Nema potom nikakve očeve priče. Za vrijeme tog prizvanog razgovora o davnim vremenima odjednom, in medias res, u vodenicu ulazi vodenjak kao stvarni lik koji je dalje s njima lik u priči i plaši ih. Ništa se više ne događa osim silnoga straha i kiše koja počne padati i pada do dana. Cijelu predaju možemo označiti memoratom, evociranjem vremena kad i kako se pripovijedalo, ali i kao nastojanje da se analogijom mjesta (vodenica) i situacije (pričanje priča) uspostavi otvoren, protočan, pouzdan kanal sa starim vremenima koja nisu mrtva i šalju svoje glasnike u očevo vrijeme (vodenjaka), a ostaju otvorenima i u pripovjedačevo doba. Ispričan sadržaj s dijelovima osobnih sjećanja ističe vremensku komponentu baš tim izravnim vezivanjem na starije ili pravremenske događaje. Najčešće je uvodna figura upravo ta navedena brza promjena pripovjedačeva fokusa sa situacije koja ga je podsjetila na priču,

${ }^{15}$ To jest ono što se u znanosti naziva komunikacijskim aspektom usmene književnosti tek od 20 . stoljeća, premda su značaj i značenje usmenosti njezin iskonski biljeg, danas bismo kazali brend.

${ }^{16}$ Tako M. Bošković-Stulli piše o svojem najboljem kazivaču, Stipi Loviću, da je priče pričao svježe, duhovito, opširno, s izvanrednim opažanjem detalja, a ipak ne razvučeno. Pripovijedao je i zgodne epizode iz svojega života, ali i o umoru koji ga je stigao s godinama i želji da posao preuzmu sinovi; ispričane priče je čuo u selu, brojne od prijatelja Mate Pavića i navodi da se oni uvečer za zimskih i jesenskih večeri sastaju i jedan drugome pričaju priče. 
na siže koji govori i u koji sam sebe uvlači kao protagonista, premda je doba priče neodređeno: davno, svevremensko i bezvremensko.

Ili:

Kad sam ja bio mali pa me otac poslao u mlin da idem u Đakovo samljeti žito i natovari mi u kola, nek nemeljem kod Ćosa, jer Ćose lažu i varaju. Kad sam ja došo u selo već tamo, do mlina, pitam je l' mogu samljet.

Kaže: - Moreš

- A kako ti ime?

- Pa - kaže - Ćoso.

Ajd sad ja neću kod Ćose mljet, otac je kazo da ne meljem kod Ćose. A ja okreni dalje do drugog mlina, pa stanem opet i pitam... (IEF Rkp 259: br. 27) ${ }^{17}$

Kazivač je istodobno i mali kojega je otac poslao u Đakovo u mlin i mali iz priče koji će u drugoj priči nadmudriti Ćosu. Ta dvostruka fokalizacija - na osobno sjećanje izgovoreno u ich-formi, konkretizirano i navodom stvarnoga mjesta (Đakova) i na siže priče - dinamizira pripovijedanje i privlači pozornost, ovjerava priču tako da tipskomu, znanomu motivu (AT 1962+1892) podaruje istinitost i lokalni kontekst. Istodobno je to i vremenska veza s ocem, njegovim dobom i pričom. Promjena pripovjedačke perspektive naglim iskakanjem iz pripovjedačkog vremena ima dubokoga smisla $u$ kulturi sjećanja (i pojedinca i zajednice). Vremenska protočnost, evociranje predaka, njihovih iskustava i priča grade horizont smisla i vremena. Jer naša prošlost ne vrijedi ako je ne možemo s nekim podijeliti. Ona zadobiva smisao tek kad se s njom uspostavi odnos, a pričanje priča i jest uvijek i sjećanje i prisjećanje na prošlost i odvija se u zajednici. Kazivačeva priča ponajprije za njega (a tek potom i za zajednicu koja je dijeli) dobiva smisao kad afektivno i emotivno rekonstruira prošlost, kad u pripovijedanje uključuje i sjećanje na pripovijedanje svojega oca (Asmann 2006: 48-49). Figure sjećanja su nužno aktualizirane u vremenu i materijalizirane u određenom prostoru pa su vremenski i prostorno konkretne, premda ne moraju odgovarati stvarnim ni vremenskim ni prostornim odrednicama. Uvijek su i stvarne i nestvarne, i pomalo mitske jer se vežu na pravremenske ili izvanredne a ne svakidašnje događaje (Asmann 2006: 54): omarina, vodenica, mlin, livada, šuma, domaći pejzaži koji odgovaraju i praslikama i stvarnim krajolicima...; noć, lani, davno, prije "ne znam prije koliko godina, ali davno", prije sto godina...

${ }^{17}$ Takvi umješni pripovjedački postupci su ipak rijetki i tek se vješti kazivači mogu igrati i jezikom i strukturom priče. U istoga kazivača (Ilija Đuretin Grgočević, r. 1887., samouk) nalazimo isti postupak i u drugoj priči koju je kazivao i na koju ga je potaknulo osobno sjećanje: bratu je u igri slučajno razbio glavu pa je od straha od majke pobjegao od kuće i... dalje je priča o nadmudrivanju lopova (IEF Rkp. 259: br. 28). 


\section{KRAJOLIK I LOKALNI PROSTOR}

Uz ta se sjećanja otvaraju i slike krajolika. Ma koliko bio pritajen i gotovo nevidljiv prema općim tipskim značajkama žanra, krajolik s topografskim odrednicama nije zanemariv u suvremenim zapisima. Dapače. Njegov opis može nalikovati žanr-slikama koje se raskrivaju u svakoj općoj stereotipnoj percepciji arhetipskih slika Slavonije (u pjesmama, na slikama): kukuruzišta, pašnjaci, svinjari, konji, šume, obale potoka... ${ }^{18}$ On jest u pričama i opći: odgovara idiličnim krajolicima 18. i 19. stoljeća s Waldingerovih ili nekih drugih slika, a može se uzdići i na razinu simbola, znaka, može biti semiotiziran (isto: 70). Međutim, on u pričama uvijek iscrtava konkretni domaći prostor iz doba zapisa, dakle iz kazivačeva doba. Neka kao primjer posluži sačuvana atmosfera kad je M. Bošković-Stulli zapisala antologijsku hrvatsku bajku o životinjskoj mladenki, Babinu Bilku. Bilo je to u lipnju 1957. u Gorjanima. Kazivao ju je Stipan Lović, tada star 63 godine: ${ }^{19}$

To je jedan od mojih najljepših doživljaja s terena. Rano ujutro pošao je kravom u pašu do njihove kolebe u polju oko $5 \mathrm{~km}$ daleko od Gorjana. Ja sam stigla onamo oko 8 sati i $30 \mathrm{~min}$. i ostala sa Stipom cijeli dan, sve do šest poslije podne, kada smo se vratili zajedno sa kravom. Tamo sam osjetila puni sadržaj usporedbe po kojoj su slavonska žita slična moru. Svuda naokolo bez kraja ravnica i na njoj zelena žita, talasaju se i prelijevaju na vjetru. Sunce je užeglo, a mi smo kraj kolibe uhvatili malo hlada. Tako sjedimo cijeli dan na zemlji i cijeli dan mi Stipan kazuje svoju priču o zečjem pastiru Ivanu. Nije je završio sve do povratka, tako da sam još putem morala pisati hodajući [...] U podne kad je trebalo jesti, podijelili smo obroke: moje konzerve, Stipin kruh i sir. Usto je Stipa napravio mašćenice, mastio šnite na vatri, baš onako kako se i u njegovoj priči kazuje, pa smo i to jeli. (IEF Rkp. 259: III)

Kad ne bismo znali da je to opis stvarne situacije, mogli bismo ga proglasiti literarnom ladanjskom slavonskom žanr-slikom. Ili u jednoj priči iz Šaptinovaca:

Gajdaš je išao na "salaš, a to su svinjci i salaš bili tam izvan polja, tam prema šumi, ispod šume, marva je išla u šumu”. (IEF Rkp. 930: br. 14)

${ }^{18}$ Pripovijetke u tome kraju nazivaju pripovitke, u selu se pripovijedaju zimi na prelu ili posilu, "bake ih pričaju djeci, dok ih mladići pripovijedaju, kada čuvaju goveda ili svinje, ili opet žene, kada češljaju (čiju) perje" (Papratović 1940: 87).

${ }^{19}$ Priču je čuo od starijih u Gorjanima. Sačuvan je i rukopisni zapis Bošković-Stulli u terenskim bilježnicama koji je nastajao za vrijeme kazivanja te prepisan tekst u rukopisnoj zbirci. Objavljena je u brojnim izdanjima (jedno i na njemačkom), dramatizirana i iskorištena za dokumentarni film HRT-a. O kazivaču, Stipi Loviću, znamo da je bio najzanimljiviji kazivač iz Gorjana, pun života i veselja, duhovit. Priče je pričao svježe, s izvanrednim opažanjem detalja, a ne razvučeno. 
Krajolik je u slavonskim pričama uvijek lokalan i omeđen. Pripovjedači opisuju svoju okolicu i kad pripovijedaju bajke jer priča daje značenje mjestu, a mjesto potvrđuje događaje. Granica sela, općine, kotara sastavni je dio lokalnoga, skupnoga identiteta: blizak, okom ili iskustvom dohvatljiv zemljovid uvijek daje sigurnost priči i kretanju aktera, on ocrtava granicu između "nas" i drugih. Predaja uspostavlja važnost, katkad i vrijednosnu hijerarhiju pojedinih mjesta: za nju je bitan što podrobniji opis mikrolokaliteta - livade, ulice, križanja, istaknutog drveta, kolibe u polju..., ali i situiranje događaja $u$ širi prostor (ako se tamo odvija) oko sela ili još dalje. Topografske odrednice su stabilni znakovi u prirodnome, stvarnome prostoru koji stvaraju gusto prepletenu mrežu znanih mikrolokaliteta i njihovih međusobnih odnosa. Oni su oslonac zajednici, sigurnost prepoznavanja i prihvaćanja vjerodostojnosti ili zbiljnosti priče - i one u negdašnjem i one u današnjem vremenu. Oni bivaju na mjestu sve "do današnjih dana" kao opipljiva svjedočanstva prošlih događaja. Taj konkretni svijet, imenovani prostor koji je nerijetko i pozornicom događaja, nudi sliku trajnosti i stabilnosti pa je, prema tome, u zajednici i društveno određen i verificiran. Te oznake ili tragovi predstavljaju istodobno i prošlo doba i sadašnji trenutak. U širem smislu mogu biti i simbol identiteta zajednice i sidrište sjećanja (Halbwachs, prema Assmann 2006: 54).

"Pojmovi prostora i vremena kolektivnog pamćenja životno su povezani s oblicima komunikacije određene grupe, a ta je veza afektivna i vrijednosna. U njoj se prostor i vrijeme pojavljuju kao domovina i priča o životu, puni smisla i značenja za samopercepciju i ciljeve grupe. Figure sjećanja 'istodobno su modeli, primjeri i neka vrst pouka. U njima je iskazano opće stajalište grupe; oni reproduciraju ne samo njezinu prošlost, već definiraju i njezino biće, njezine značajke i slabosti'”. (Assmann 2006: 55)

Katkad je nebitan siže, važno je istaknuti mjesto jer sukus, ideja predaje počiva na odnosu vremena i mjesta:

Vračara šalje majku s vještičjim podmetnutim djetetom prije sunca "do ćuprije kod Bijelog Manastira” da ga bace. (IEF Rkp. 259: br. 1; istakla Lj. M.)

[...] isto su tak išli konje napasivat, znate, a u Žagrovcu - znaš čika Jozo đe sad ćošak ovog kanala - tu je bila koliba i njih dvojica su došli tamo. (IEF Rkp. 930: br. 55; istakla Lj. M.).

Kad sam išao u Našice, baš na Badnjak ujutru, znaš. Idem kupit si kaputa za Božić. Idem ja, idem, kad prošo Đurđenovac, a sad ću s malom prugom, znaš. A to je bilo ujutro, još pet sati, mrak puni. (IEF Rkp. 930: br. 65; istakla Lj. M.)

Prije osam godina išo iz Feričanaca na Sisvete i tamo, kod popove livade kod Beljevine, znaš, preko s kolima još moj otac bio. S kolima išli mi i kak smo 
išli iz Bokšića preko onih livada prema šumi za Beljevine, tam di su one Sepetarove livade, znaš, i direktno tamo prelazi, al to ide ovako kas, al onak' u zraku možda svoji dva-tri metra visine. A bogme mogu kast da sam vidio i to se dobro sećam, nikad zaboravit ne mogu. (Rkp. IEF 930: br. 70; istakla Lj. M.)

Osobno obraćanje istraživaču, opetovano "znaš" u više iskaza, uspostavlja povjerljiv, intiman odnos, dijeljenje tajne. Pomna i za priču nepotrebna rekonstrukcija svih mjesta i međusobnih daljinskih odnosa te vremena (Svisveti, Badnjak) i kazivaču i publici je zalog zbiljnosti i neporecivosti izrečenoga. I za mitske i za povijesne predaje usidrene u lokalni prostor ključna je svijest o publici kojoj se priča. Njoj su namijenjeni neuobičajeni, neočekivani dijelovi teksta (utoliko i variraju ovisno o publici/istraživaču kad je sam s pripovjedačem): opisi pejzaža, detaljni opisi odnosa između mjesta radnje, lokalni nazivi. To je s jedne strane udomaćivanje teksta, što odgovara žanrovskim zakonitostima i stalnim mjestima u svim interpretacijama, ali i stalna pripovjedačka manira koja ozbiljuje i učvršćuje ispripovijedani događaj te potvrđuje njegovu važnost do danas. Ispričani prošli dramatični događaji prodrli su u sadašnjost najčešće upravo podatkom o mjestu. Za autsajdera, osobu izvan zajednice, lokalno se mjesto može učiniti samo još jednom točkom u polju, grmlje, križanje, prteni put, šuma, stup... Međutim, upravo su te male nezamjetne kote i emotivno i povijesno nezamjenjiv pejzaž lokalne zajednice i snažan nositelj identiteta. U taj su krajolik utisnute unutarnje veze i razumijevanje svijeta.

I onda ide, stoji i titra, titra, titra, titra i onda najedanput nestane. Onda ope. I onda sam jedanput išla iz nadnice, to smo bili u Beljevinama tamo, [...] i oko devet sati kad smo išli doma, onda ne sam' da sam ja vidla, neg' tkogod je bio tamo. To tako ide ko vatralj, ko na lopati. (IEF Rkp. 930: br. 32; istakla Lj. M.)

Ujutro u tri sata išao sam ja i još jedan naš u Đurđenovac, rano, i onda kako ova cesta ide za Đurđenovac, tu je bila prtena blatna staza. Tu smo išli i ide neko svetlo odande iz šume, nuz šumu, skroz ide, ide, ide, pa prama nama. Ide. Prama nama. Al sad će bit dobro. Mrak bio. Sad će bit dobro, sad će nam prisvetlit. Kad dođe do nas, preskoči preko puta, ide s druge strane i sad se vraća nazad. I ode tamo ispod šume prama Todorovcu i nas napustilo. Al sve izgledalo kao da neki brus ima. A ovaj stariji bio od mene, kaže: - To je svećica, to britvu nosi pa brije! (Rkp. IEF 930: br. 111; istakla Lj. M.)

I tako on išo za tim svetlom, išo, išo, jedamput se potepe, di je - on već u groblju sušinjaračkome. E sad kad je vidio di je, onda je spazio u Mederovcu svetlo i ošinio je pravac tamo dok nije došao na onu stazu za Sušine. Kad je došo tamo, onda okrene za Sušine, baš bilo neko Mitrovo - ili što je bilo, jesen 
je to bila - skrene se tamo kod đaka Bogoljuba, kod koga li tamo, popio par čaša rakije i sad ide kući. (IEF Rkp. 930: br. 69; istakla Lj. M.)

Svećici nitko od protagonista tih triju predaja nije pobjegao. U posljednjem ga je tekstu dočekala nakon rakije na putu u Šaptinovce. Prema pričanju i topografskim detaljima se i danas točno može rekonstruirati put kojim je prolazio čovjek kojega je uplašila svećica. Nisu bili dovoljni svjedoci koji su ga susreli uz rakiju, susret s mitskim bićem je upravo zbog vjerodostojnosti događaja morao biti pomno vezan uz mjesta. Ti mali nevažni lokaliteti, znani ponajprije pripovjedaču i publici, iscrtavaju selo, okolicu, kartografiraju zavičaj te stvaraju hijerarhiju važnih i manje važnih mjesta, a i osoba. Ta su mjesta u priči u isti mah materijalna, simbolička i funkcionalna. Materijalna su jer stvarno postoje, a simboličku im funkciju dodjeljuje upravo priča. $\mathrm{Pu}-$ blika, zajednica koja dijeli priču prepoznaje ih i mjestima pamćenja te time i važnima u kolektivnoj memoriji (Nora 2006: 36-37).

Priča omogućuje i publici da svijet vidi drukčije - s distance, mirno, bez afekta, ali s aktivnim sudjelovanjem te prepoznavanjem i poznavanjem ključnih točaka pripovijesti. Time priča i o povijesnom i o mitskom postaje podjednako katarzična i za pripovjedača i za publiku. Ona oslobađa od straha, tako imanentnog mitskim predajama, ona nas mijenja odvodeći nas u neko drugo vrijeme i na druga mjesta (daleka a opet bliska) gdje stvari možemo doživjeti drukčije. Dopušta praćenje događaja s distance, sagledavanje "s onu stranu priče". Ukratko, to je "moć posrednog poistovjećivanja u mašti" (Kearney 2009: 138).

Osobnim intervencijama znani tradicijski motivi, figure i sižei postaju retorički dinamični jer su u napetu odnosu s vremenom pripovjedača (i publike). To nije uobičajeni konflikt unutar pripovjedačkih sižea, između čudesnog, povijesnog i poučnog, poglavito kad je riječ o predaji u kojoj je pouka gotovo kanonizirana žanrovska sastavnica. Opetovano osuvremenjivanje diskursa premošćuje vrijeme i uspostavlja trajan dinamičan odnos. Ta napetost između svijeta priče (koji može pripadati davnome dobu) i sadašnjega svijeta zapravo je opći stvaralački princip priče i razlog njezina ponavljanja i trajanja. ${ }^{20}$ To su mjesta u tekstovima koja pokazuju kako se uspostavlja i dijakronijski protočni niz jer, primjerice, očeva/djedova priča postaje i mojom, odgovara i na moja pitanja, pitanja moga doba pa je zato i

${ }^{20} \mathrm{Ti}$ znakovi vremena u tekstovima ne pripadaju samo novijim tekstovima; oni su evidentni u čitavu hodu usmene književnosti u zapisima koji su nastajali pretežno prema pričanjima i poslije nisu redigirani ili literarizirani. Iščitavaju se, primjerice, u njemačkim pričama od 18. stoljeća, kad je bajka živ i produktivan žanr; tradiciju takvih zapisa prekidaju braća Grimm svojim idealom prirodne narodne poezije. Stiliziraju bajku kao tekst koji je bezvremen, s onu stranu povijesnih ili aktualnih događaja. Izniman uspjeh njihove zbirke okončao je zapravo objavljivanje tekstova koji su književno otvoreni i živi te povijesno aktualni (Matuschek 2014: 13). 
pričam, odvija se i na "našim" mjestima i nije bitno otkuda je amo dospjela i tko je još s nama dijeli. Stoga je svaka inačica samosvojna i jedinstvena priča.

Usmeni se tekstovi mogu interpretirati kao kultura sjećanja u assmannovskom poimanju toga termina jer kazivači govore o događajima kao o pričama koje su zapamtili kao svjedoci (ili iz dramatičnih vijesti koje su dopirale raznolikim putovima, ne samo usmenim) ili iz pričanja starijih u svojoj zajednici. ${ }^{21}$ One se mogu dijelom interpretirati i kao dio imagologije, romantičarskog uprizorenja i krajolika, i događaja, i likova, i interpretacija (Pageaux 2009). Predaje o lokalnim junacima, često anonimnima i neznanima izvan toga kraja, a pogotovo u "velikoj povijesti", dobra su potka za priču koja u stvarnome kontekstu poprima potpuno drukčije obrise od priče u knjigama. Ona je pritom neobična, drukčija od znanih, pa premda nerijetko pripada narativnom imaginacijskom sadržaju europskih priča, izravno pobuđuje bliskost s krajem i ljudima.

\section{NAVEDENA LITERATURA I IZVORI}

Aarne, Antti i Stith Thompson. 1961. The Types of the Folktale. A Classification and Bibliographie. Antti Aarne's Verzeichnis der Märchentypen (FF Communications No.3). [Second revision. FF Communications 184]. Helsinki: Suomalainen Tiedeakatemia.

Assmann, Jan. 2006. "Kultura sjećanja”. U Kultura pamćenja i sjećanja. Maja Brkljačić i Sandra Prlenda, ur. Zagreb: Golden marketing-Tehnička knjiga, 45-78.

Bošković-Stulli, Maja. 1957. Folklorna građa okolice Đakova. IEF Rkp 259.

Certeau, de Michel. 2002. Invencija svakodnevice. Zagreb: Naklada MD.

Dégh, Linda. 2001. Legend and Belief. Dialectics of a Folklore Genre. Bloomington, Indiananapolis: Indiana University Press.

Grimm, Brüder. 1993. Deutsche Sagen, 1. Hans-Jörg Uther, ur. München: Diederichs.

Horvath, Josip i Jakša Ravlić. 1956. "Pisma Ljudevitu Gaju”. Građa za povijest književnosti hrvatske 26: 435.

Ilić, Luka Oriovčanin. 1846. Narodni slavonski običaji, sabrani i popisani. Zagreb.

Kearney, Richard. 2009. O pričama. Zagreb: Naklada Jesenski i Turk.

Lesar, Juraj. "Narodne pripovijetke iz Podgajaca”. Zbornik za narodni život i običaje 11/2 (1906); 12/1 (1907).

Lovretić, Josip. 1990. Otok. Pretisak. Vinkovci: Privlačica.

Lukić, Luka. 1898-1901. Varoš (zabave, "narodna duša", "narodni um"). ONŽO, SZ 96a: 578.

Lukić, Luka. 1911-1912. Pripovjetke. ONŽO, SZ 128b: 443.

Lukić, Luka. 1911-1912. Vjerovanja iz Klakarja (raznovrsna građa). ONŽO, SZ 128c: 184.

Marks, Ljiljana. 1974. Narodne pripovijetke, predaje i pjesme iz Šaptinovaca (Slavonija), 1. IEF Rkp 930.

${ }^{21}$ U zbirkama Papratović, Bošković-Stulli i Marks kazivači su uglavnom rođeni potkraj 19. i u prvim desetljećima 20. stoljeća. 
Marks, Ljiljana. 2009. "Legends about the Grabancijaš Dijak in the 19th Century and in Contemporary Writings". Acta Ethnographica Hungarica 54/2: 319-336. [http://dx.doi. org/10.1556/AEthn.54.2009.2.5]

Matuschek, Stefan. 2014. "Es war einmal. Das Märchen als gegenwartsorientierte, dynamische Gattung". Fabula 55/1-2: 13-25. [http://dx.doi.org/10.1515/fabula-2014-0002]

Nora, Pierre. 2006. "Između Pamćenja i Historije. Problematika mjestâ". U Kultura pamćenja i sjećanja. Maja Brkljačić i Sandra Prlenda, ur. Zagreb: Golden marketing-Tehnička knjiga, 21-43.

Pageaux, Daniel-Henri. 2009. "Od kulturnog imaginarija do imaginarnog”. U Kako vidimo strane zemlje. Uvod u imagologiju. Davor Dukić i dr., ur. Zagreb: Srednja Europa, 125-150.

Papratović, Milena. 1940. "Narodne pripovijetke iz okolice Đakova s komentarima i poredbenim pregledom”. Zbornik za narodni život i običaje 32/2: 85-195.

Smičiklas, Tadija. 1874.-1879. “Narodne pripovijesti”. ONŽO HAZU, SZ 2: 148.

Smičiklas, Tadija. "Narodne pripovijetke iz osječke okolice u Slavoniji". Zbornik za narodni život i običaje 15 (1910), 16/1-2 (1911) 17/1-2 (1912), 18/1-2 (1913).

Stojanović, Mijat. 1867. Pučke pripoviedke i pjesme. [Sabrao i spisao]. Zagreb.

Stojanović, Mijat. 1879. Šala i zbilja. Sbirka narodnih pripoviedaka sa tri dodatka: Narodne poslovice. Narodne zagonetke i Putositnica. [Sabrao i priredio]. Senj.

Stojanović, Mijat. 1879a. Narodne pripoviedke. [Sabrao i priredio za mladež]. Zagreb.

Tangherlini, Timothy. 1990. “'It Happened Not to Far from Here.... A Survey of Legend Theory and Characterization". Western Folklore 49/4: 371-390. [http://dx.doi.org/ 10.2307/1499751]

Uther, Hans-Jörg. 2004. "The Types of International Folktales. A Classification and Bibliography Based on the System of Antti Aarne and Stith Thompson". FF Communications 284-285. Helsinki: Suomalainen Tiedeakatemia.

\section{“LET ME TELL YOU, THIS HAPPENED WHEN ...". HISTORY, TIME AND LANDSCAPE IN LEGENDS FROM SLAVONIJA}

\section{SUMMARY}

I take historical legends to be a dynamic genre of oral literature, oral history and culture in general. They represent a dialogue with the past from the temporal (and educational) perspective of the narrator who, while speaking of the past, also provides a commentary on the present time. The analysed texts for the most part come from two manuscript collections (the vicinity of Đakovo, 1957 and Šaptinovci 1974/1975). It is a region that did not provide any great heroes in Croatian history, but this does not necessarily indicate a lack of awareness of the historical period which could be related in a story. From within these legends springs forth the narrator's concept of history: important milestones that represent turning points not only in the wide world, but also in this small community (First and Second World War), the importance of local aristocracy (earls) who act as a substitute for the usual feudal 
fairytale world. Adventures of local outlaws are evoked, as well as tales about prominent figures pertaining to the Croatian culture in general (Strossmayer), who are the main characters in events taking place in the local community. The retold events are narratively constructed as legends on the verge of memorates and mythical tales. In doing so, the legends denote permanent and firm historical points and mythical places, but they simultaneously update and vivify them by retelling them.

They can be interpreted as culture of remembrance in the Assman's sense of the term because the narrators, for the most part born at the turn of the 19th and 20th century, (the majority in both collections), speak of events in terms of stories they remember as eyewitnesses (or from dramatic pieces of news that spread in diverse manners, by no means only verbally) or stories they heard told by the community elders. They can also in a way be interpreted as part of imagology, a romantic representation of landscapes, events, characters and interpretations (Pageaux 2009). Legends of local heroes, often anonymous and unknown in the wider frame, especially in the 'big historical picture', make a fine yarn for the story, which in the realistic context, takes contours completely differently from the stories we find in books. Thus, it is singular, different from the famous stories, and though it frequently belongs to the narrative imaginational content of European tales, it still directly invokes a sense of intimacy with the land and the people.

Keywords: legends, topography, the culture of memory, Slavonija, Croatia 